\title{
Functional Integration of Embryonic Stem Cell-Derived Neurons in Hippocampal Slice Cultures
}

\author{
Felix Benninger, ${ }^{1,2}$ Heinz Beck, ${ }^{2}$ Marius Wernig, ${ }^{1}$ Kerry L. Tucker, ${ }^{4}$ Oliver Brüstle, ${ }^{1}$ and Björn Scheffler ${ }^{3}$ \\ ${ }^{1}$ Institute of Reconstructive Neurobiology and Departments of ${ }^{2}$ Epileptology and ${ }^{3}$ Neuropathology, University of Bonn Medical Center, D-53105 Bonn, \\ Germany, and ${ }^{4}$ Interdisciplinary Center for Neurosciences, University of Heidelberg, D-69120 Heidelberg, Germany
}

The generation of neurons and glia from pluripotent embryonic stem (ES) cells represents a promising strategy for the study of CNS development and repair. ES cell-derived neural precursors have been shown to develop into morphologically mature neurons and glia when grafted into brain and spinal cord. However, there is a surprising shortage of data concerning the functional integration of ES cell-derived neurons (ESNs) into the host CNS tissue. Here, we use ES cells engineered to express enhanced green fluorescent protein (EGFP) only in neuronal progeny to study the functional properties of ESNs during integration into long-term hippocampal slice cultures. After incorporation into the dentate gyrus, $\mathrm{EGFP}^{+}$donor neurons display a gradual maturation of their intrinsic discharge behavior and a concomitant increase in the density of voltage-gated $\mathrm{Na}^{+}$and $\mathrm{K}^{+}$channels. Integrated ESNs express AMPA and $\mathrm{GABA}_{\mathrm{A}}$ receptor subunits. Most importantly, neurons derived from ES cells receive functional glutamatergic and GABAergic synapses from host neurons. Specifically, we demonstrate that host perforant path axons form synapses onto integrated ESNs. These synapses between host and ES cell-derived neurons display pronounced paired-pulse facilitation indicative of intact presynaptic short-term plasticity. Thus, ES cellderived neural precursors generate functionally active neurons capable of integrating into the brain circuitry.

Key words: ES cells; tau; transplantation; electrophysiology; slice culture; hippocampus

\section{Introduction}

The limited regenerative potential of the CNS remains a major challenge for basic and clinical neuroscience (Björklund and Lindvall, 2000). In principle, there appear to be two strategies for restoring neuronal function. Given that endogenous stem cells persist in the adult CNS, one strategy would be to augment the process of adult neurogenesis via extrinsic stimuli and to recruit newly formed endogenous neurons into lesioned areas. Alternatively, cell transplantation might be used to introduce extrinsic neurons into damaged host brain regions. Both strategies critically depend on the question of whether young neurons can functionally integrate with the established host brain circuitry.

Rodent studies on adult neurogenesis have provided the first evidence that newborn hippocampal neurons can indeed undergo functional maturation. The intrinsic physiological properties of a subpopulation of newly formed dentate granule neurons appear comparable with those of neighboring, preexisting granule cells. In addition, these cells have been shown to receive synaptic input via the perforant path [i.e., the major afferent pathway to the dentate gyrus (DG) (van Praag et al., 2002)]. However,

Received Jan. 27, 2003; revised May 30, 2003; accepted June 9, 2003.

This work was supported by the Hertie Foundation (M.W. and 0.B.), the Deutsche Forschungsgemeinschaft (TR-SFB 3) (0.B., B.S., and H.B.), the BONFOR program (F.B., H.B., O.B., and B.S.), and the Evelyn F. McKnight Brain Research Foundation (B.S.). We thank Yves-Alain Barde for providing the tau EGFP knock-in ES cells. Rachel Buschwald and Barbara Steinfarz have greatly supported the cell and tissue culture work, and Jörg Wellmer has performed the field potential recordings.

Correspondence should be addressed to Dr. Oliver Brüstle, Institute of Reconstructive Neurobiology, University of Bonn Medical Center, Sigmund-Freud-Strasse 25, D-53105 Bonn, Germany. E-mail: brustle@uni-bonn.de.

B. Scheffler's present address: McKnight Brain Institute, University of Florida, Gainesville, FL 32610.

Copyright $\odot 2003$ Society for Neuroscience $\quad$ 0270-6474/03/237075-09\$15.00/0 adult neurogenesis appears to be mostly restricted to the subventricular zone and the dentate gyrus (Gage et al., 1995, 1998; Scheffler et al., 1999; Alvarez-Buylla and Garcia-Verdugo, 2002). Currently, it remains uncertain whether neurons generated in these areas could be efficiently used for neuronal replacement in other brain regions.

Transplantation of neural precursor cells represents an alternative route to replace lost or damaged neurons in the adult CNS. Although this approach has been developed to a clinical scale (Björklund and Lindvall, 2000; Lindvall, 2001), it is currently complicated by its dependency on fetal donor tissue. The advent of embryonic stem (ES) cell technology has provided novel prospects for generating neural donor cells in unlimited numbers in vitro. Neurons and glia have been efficiently derived from both rodent and human ES cells (Okabe et al., 1996; Brüstle et al., 1999; Reubinoff et al., 2001; Zhang et al., 2001). During transplantation, ES cell-derived neural precursors incorporate widely throughout the CNS and differentiate into neurons, astrocytes, and oligodendrocytes (Brüstle et al., 1997, 1999). So far, functional studies on ES cell-derived neurons (ESNs) have been primarily restricted to monolayer cultures (Bain et al., 1995; Strübing et al., 1995, 1997; Finley et al., 1996). In contrast, little is known about the functional maturation of individual ES-cell derived neurons after transplantation into CNS tissue (Kim et al., 2002).

In the present work, we examined the integration of enhanced green fluorescent protein (EGFP)-expressing ESNs into the dentate gyrus of hippocampal slice cultures. The intrinsic properties of maturing donor cells and their synaptic integration were characterized over a period of up to 3 weeks. Our findings demon- 
strate that ESNs undergo functional maturation and incorporate into preexisting neuronal circuits of the host tissue.

\section{Materials and Methods}

Generation of ES cell-derived neural precursors. Tau EGFP knock-in ES cells were used to permit visualization of ESNs in vital slice cultures (Tucker et al., 2001). These cells are derived from the J1 ES cell line (Li et al., 1992) and carry the cDNA for EGFP targeted in-frame into exon 1 of the tau gene. This results in a fusion protein consisting of the first 31 amino acids of tau and EGFP. After in vitro differentiation of this cell line, EGFP fluorescence has been found to be restricted to neuronal progeny (Wernig et al., 2002).

The generation of ES cell-derived neural precursors from tau EGFP knock-in ES cells was performed as described previously (Okabe et al., 1996; Wernig et al., 2002). Briefly, ES cells were aggregated to embryoid bodies, which were subsequently plated and propagated in ITSFn medium (DMEM-F12 supplemented with $5 \mu \mathrm{g} / \mathrm{ml}$ insulin, $50 \mu \mathrm{g} / \mathrm{ml}$ transferrin, $30 \mathrm{~nm}$ sodium selenite, and $5 \mu \mathrm{g} / \mathrm{ml}$ fibronectin) for $5-7 \mathrm{~d}$. Cells were then trypsinized, triturated to a single-cell suspension, and replated in polyornithine-coated dishes. They were then propagated for an additional 2-5 d in DMEM-F12 supplemented with $25 \mu \mathrm{g} / \mathrm{ml}$ insulin, 50 $\mu \mathrm{g} / \mathrm{ml}$ transferrin, $30 \mathrm{~nm}$ sodium selenite, $20 \mathrm{~nm}$ progesterone, $100 \mathrm{~nm}$ putrescine, $1 \mu \mathrm{g} / \mathrm{ml}$ laminin, and $10 \mathrm{ng} / \mathrm{ml}$ fibroblast growth factor 2 . Media, supplements, and growth factors were obtained from Invitrogen (Karlsruhe, Germany), R \& D Systems (Wiesbaden, Germany), and Sigma (Taufkirchen, Germany). For transplantation, donor cells were trypsinized and triturated through flame-polished Pasteur pipettes. They were then washed in calcium- and magnesium-free HBSS and concentrated to $5-8 \times 10^{4}$ cells $/ \mu$ l.

Slice culture preparation and donor cell application. Slices $(400 \mu \mathrm{m})$ containing the dentate gyrus, entorhinal cortex, and adjacent areas of the temporal cortex were prepared from 9-d-old Wistar rats (Charles River, Sulzfeld, Germany) and cultured in interphase conditions in a humidified $5 \% \mathrm{CO}_{2}$ atmosphere at $35^{\circ} \mathrm{C}$ (Stoppini et al., 1991). We chose this time point for preparation of hippocampal slice cultures, because culturing slices from older animals for prolonged periods of time has proven difficult. When prepared from young rodents, neural circuitries of the hippocampal formation are known to mature and to maintain a surprising three-dimensional, organotypic organization for many weeks in vitro (Gähwiler, 1981; Zimmer and Gähwiler, 1984; Gähwiler et al., 1997).

Cultures were started in a horse serum-containing medium, which was gradually replaced until day 5 in culture by a serum-free, defined solution based on DMEM-F12 and including the N2 and B27 supplements (Cytogen, Sinn, Germany). Under these conditions, cultured slices could be maintained for a period of up to $35 \mathrm{~d}$. Field EPSPs could be recorded in the perforant path-dentate gyrus synapse as well as the Schaffer collateral-CA1 synapse up until $33 \mathrm{~d}$ in culture, confirming the functional integrity of the preparation (data not shown). More than $75 \%$ of all of the hippocampal slices cultured under these conditions revealed a remarkable preservation of the histoarchitecture [i.e., preservation of the major neuronal subpopulations, absence of mossy fiber sprouting, and only mild gliosis (B. Scheffler, unpublished observations)]. Slices with abundant gliosis or visible neuronal loss were discarded on day 7 in culture.

Application of ES cell-derived neural precursors was performed at day $10 \pm 1$ in culture. This permitted monitoring of the maturation of ESNs for up to $21 \mathrm{~d}$ after application, while exposing donor cells to the most advanced stage of tissue differentiation obtainable in this approach. The cells were suspended in a total volume of $0.2 \mu \mathrm{l}$ and gently deposited on the surface of the slice centrally within the hilus of the dentate gyrus. On day 2 after deposition, recipient cultures were washed thoroughly with medium to remove donor cells that had not migrated into the tissue. Migration and differentiation of the donor cells was studied by epifluorescence microscopy in $2 \mathrm{~d}$ intervals. In some preparations $(n=12)$, the perforant path was labeled with a rhodamine-conjugated anterograde tracer (Microruby; Molecular Probes, Leiden, The Netherlands) [according to Kluge et al. (1998)].

5-Bromo-2' -deoxyuridine (BrdU) labeling was used to confirm the postmitotic status of the EGFP-positive ESNs. Selected slice cultures were subjected to a $48 \mathrm{hr}, 10 \mu \mathrm{M}$ BrdU pulse at days 3 and 12 after donor cell application. BrdU-treated slices were fixed and processed for immunofluorescence and confocal analysis ( $n=4$ per time point). Careful examination of $>500 \mathrm{EGFP}^{+}$cells at both stages of integration revealed no evidence of BrdU labeling among the EGFP-positive donor cells (data not shown).

Electrophysiology. At different time points after transplantation (5-7, 12-14, and 19-21 d), slice cultures were transferred to the stage of an upright microscope (Axioskop FS II; Zeiss, Göttingen, Germany). EGFP $^{+}$ESNs were readily identified using a fluorescence camera (Spot Jr.; Diagnostic Instruments/Visitron Systems, Puchheim, Germany). These cells were subsequently visualized using infrared video microscopy and differential interference contrast (DIC) optics to obtain patch-clamp recordings under visual control. For each recording, positive identification of the $\mathrm{EGFP}^{+}$donor cell was confirmed by diffusion of EGFP into the patch pipette (see Fig. 1). In addition, biocytin was included in the recording solution in 59 recordings from 24 slice cultures. In these cases, subsequent labeling with fluorophore-conjugated avidin confirmed the colocalization of EGFP and biocytin in the same cells.

For current-clamp recordings as well as recordings of voltagedependent membrane currents, the bath solution contained (in mM): 125 $\mathrm{NaCl}, 3 \mathrm{KCl}, 1.25 \mathrm{NaH}_{2} \mathrm{PO}_{4}, 25 \mathrm{NaHCO}_{3}, 2.0 \mathrm{CaCl}_{2}, 1.0 \mathrm{MgCl}_{2}$, and 20 glucose, $\mathrm{pH} 7.3, \mathrm{NaOH}$. For recordings of NMDA receptor-mediated EPSCs, glycine $(5 \mu \mathrm{M})$ was added to the extracellular solution. In addition, $\mathrm{MgCl}_{2}$ was omitted from the extracellular solution in some experiments. The blockers of synaptic transmission 6-cyano-7-nitroquinoxaline-2,3-dione disodium salt (CNQX) $(50 \mu \mathrm{M})$, bicuculline $(10 \mu \mathrm{M})$, and D- (-)-2-amino-5phosphonopentanoic acid (AP5) $(50 \mu \mathrm{M})$ or the blocker of voltage-gated $\mathrm{Na}^{+}$channels tetrodotoxin (TTX) (500 nM) were bath applied.

Glass microelectrodes were pulled from borosilicate glass (diameter, $2.0 \mathrm{~mm}$; wall thickness, $420 \mu \mathrm{m}$ ) and had a resistance of 3.0-4.5 M . For current-clamp recordings, pipettes contained (in mM): $20 \mathrm{KCl}, 120$ potassium gluconate, 10 ethyleneglycol-bis-(2-aminoethyl)-tetra acetic acid, 10 HEPES, $2 \mathrm{MgCl}_{2}$, and 2 ATP. For recordings of postsynaptic currents (PSCs), pipettes contained (in mM): 110 cesium methanesulfonate, $2 \mathrm{MgCl}_{2}$, 10 1,2-bis(2-amino-5-bromophenoxy)ethane- $N, N, N^{\prime}, N^{\prime}$-tetra-acetic acid, 2 ATP, 10 HEPES, 20 tetraethylammonium chloride, and 5 lidocaine $N$-ethyl bromide, $\mathrm{pH}$ 7.4, $\mathrm{NaOH}$. Liquid junction potentials were not compensated. All of the chemicals were purchased from Sigma.

Whole-cell voltage- and current-clamp recordings were obtained at $35^{\circ} \mathrm{C}$ using a patch-clamp amplifier (EPC9; HEKA Instruments, Lambrecht/Pfalz, Germany). After establishing the whole-cell configuration, the resting membrane potential and cell capacitance were measured. In all of the voltage-clamp recordings, the capacitance compensation circuitry of the patch-clamp amplifier was used to reduce capacitive transients. Series resistance was on average $14.9 \pm 3.5$ and was compensated by $>70 \%$. Traces were leak subtracted on-line.

PSCs were elicited by a $0.1 \mathrm{msec}$ current pulse delivered via a monopolar glass stimulation electrode. For eliciting GABAergic IPSCs, it was always necessary to place the stimulation electrode in the vicinity of the $\mathrm{EGFP}^{+}$cell. For eliciting EPSCs, stimulation electrodes were placed in either the molecular layer or the entorhinal cortex.

Data analysis. The time constants of PSC decay $(\tau)$ were determined by fitting a single exponential equation of the following form to the falling phase of the PSCs: $\mathrm{I}(t)=A_{0}+A_{1} \times[1-\exp (-t / \tau)]$, where $I(t)$ is the current amplitude at the time point $t$ and $A_{0}$ is a constant offset. Fitting and determination of $10-90 \%$ rise times of PSCs were performed using the program Igor (WaveMetrics, Lake Oswego, OR). Spike threshold was defined as the membrane potential at which the slope of the voltage trace increased abruptly during membrane charging induced by positive current pulses. Spike amplitude was measured as the voltage difference between the peak of the action potential and resting membrane potential $\left(V_{\mathrm{m}}\right)$. Spike width was calculated as spike duration at $50 \%$ of the spike amplitude.

Immunohistochemistry. Slices were fixed in $4 \%$ paraformaldehyde, $15 \%$ picric acid, and $0.1 \%$ glutaraldehyde (GA) for $15 \mathrm{~min}$ at room temperature and postfixed without GA overnight at $4^{\circ} \mathrm{C}$. Determination of donor cell invasion and immunolabeling (IL) were performed using either $10 \mu \mathrm{m}$ serial cryostat sections mounted to poly-L-lysine coated tissue slides or on free-floating slice culture specimens. 
The basic IL-buffer solution contained PBS (Seromed, Berlin, Germany) and $10 \%$ fetal calf serum (Invitrogen). After preincubation in $5 \%$ normal goat serum, we applied mouse IgG monoclonal antibodies to BrdU, (BD Biosciences, Heidelberg, Germany; 1:100) and GABA recep- $^{-}$ tors ( $\beta$-chain; clone BD17; Chemicon, Hofheim, Germany; 1:1000) as well as rabbit polyclonal antibodies to the AMPA receptor subunit glutamate receptor 1 (GluR1) (Sigma; 1:300) and the NMDA receptor subunit NMDAR1 (Chemicon; 1:1000). All of the antigens were visualized using corresponding $\mathrm{Cy} 3$ - and $\mathrm{Cy} 5$-conjugated goat secondary antibodies (Dianova, Hamburg, Germany).

Images were documented and three-dimensional reconstructions were performed using confocal microscopy and appropriate software (Leica, Pulheim, Germany). Data are expressed as means \pm SDs.

\section{Results}

\section{Incorporation of ES cell-derived neurons into hippocampal} slice cultures

The ES cells used in this study express EGFP only in neuronal progeny and thus permit a reliable identification of donorderived neurons within the host tissue (Tucker et al., 2001; Wernig et al., 2002). Donor cells were applied as immature neural precursors. Expression of EGFP indicative of neuronal differentiation became first visible at day 3 after implantation. Although this delayed expression of EGFP in donor-derived cells does not permit a well controlled investigation of the migration of these cells within the host tissue, the distribution of the engrafted $\mathrm{EGFP}^{+}$donor cells clearly indicated that they had invaded the slice preparation after deposition. Seven days after transplantation, ESNs were found at up to $80 \mu \mathrm{m}$ from the slice culture surface $(67.5 \pm 18.9 \mu \mathrm{m} ; n=4$ slice cultures). After 2 and 3 weeks, $\mathrm{EGFP}^{+}$cells were detected at distances of up to $130 \mu \mathrm{m}$ from the surface $(110 \pm 8.2$ and $110 \pm 14.1 \mu \mathrm{m} ; n=5$ and 4 slice cultures, respectively). Furthermore, ESNs had migrated up to several hundred micrometers away from the engraftment site in a horizontal plane by 2 weeks after deposition. At this time, ESNs were found throughout the dentate gyrus hilar region. Most of the $\mathrm{EGFP}^{+}$cells were localized within or close to the DG granule cell layer, with only a few cells in the CA3 and CA1 regions. The majority of the ESNs we analyzed functionally were located within the granule cell layer or at its hilar border. The remainder of the neurons selected for patch-clamp analysis was located within the hilar region (Fig. 1A, locations of recorded cells are indicated by dots). During the first week, most EGFP ${ }^{+}$cells had round to oval cell bodies extending one or two small processes with few ramifications. At later stages, more complex neuronal phenotypes became visible (Fig. $1 B$ ).

\section{Intrinsic properties of incorporated ESNs}

Incorporated ESNs were identified by virtue of their EGFP fluorescence, and patch-clamp recordings from donor cells $(n=212)$ were performed using infrared differential interference contrast optics. In every case, diffusion of EGFP into the patch pipette confirmed that the recorded cell was indeed an ES cell-derived neuron (Fig. $1 C_{1}-C_{3}$ ). Patch-clamp recordings in the currentclamp configuration allowed us to determine the passive membrane characteristics of ESNs at different time points (5-7, 12-14, and 19-21 d after engraftment). With time in culture, the donorcell capacitance increased, and input resistance decreased. In addition, ESNs displayed a progressively more negative membrane potential similar to the developmental maturation of putative newborn hippocampal granule neurons in adult animals (Table 1) (Wang et al., 2000).

We next examined the discharge behavior of ESNs at these different time points. During current injection, most cells re-
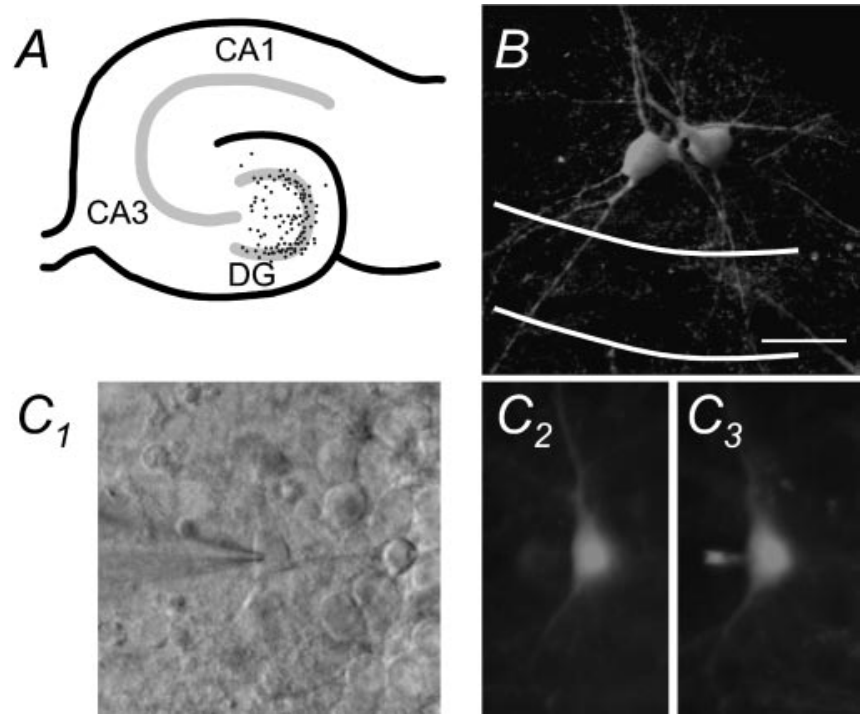

Figure 1. Morphology and distribution of functionally analyzed ESNs. A, Schematic representation of a hippocampal slice culture showing the distribution of incorporated EGFP-labeled ESNs used for functional analyses. CA1, CA1 subfield; CA3, CA3 subfield of the hippocampus. $B$, Confocal image of two EGFP ${ }^{+}$neurons 3 weeks after engraftment (3-dimensional reconstruction of 16 individual planes taken from a fixed slice). Scale bar, $10 \mu \mathrm{m} . C_{1}-C_{3}$, Infrared DIC image $\left(C_{1}\right)$ and fluorescence image $\left(C_{2}\right)$ of an EGFP ${ }^{+}$donor neuron after formation of a gigaseal. In all of the recordings, diffusion of EGFP into the pipette served as confirmation of the donor cell identity $\left(C_{3}\right)$.

Table 1. Passive electrical properties of ESNs

\begin{tabular}{llccc}
\hline & \multicolumn{3}{l}{ ESNs } & \\
\cline { 2 - 4 } & Days 5-7 & Days 12-14 & Days 19-21 & Endogenous neurons \\
\hline Cap. (pF) & $13.2 \pm 1.0$ & $23.9 \pm 2.5$ & $23.3 \pm 1.5$ & $42.3 \pm 6.4$ \\
$R_{\text {inp }}(\mathrm{M} \Omega)$ & $495.4 \pm 37.7$ & $379.0 \pm 34.9$ & $398.4 \pm 35.1$ & $313.8 \pm 42.7$ \\
RMP $(\mathrm{mV})$ & $-43.5 \pm 3.4$ & $-49.1 \pm 4.1$ & $-50.3 \pm 3.4$ & $-57.7 \pm 17.8$ \\
$n$ & 42 & 18 & 35 & 7 \\
\hline
\end{tabular}

Cap., Capacitance; $R_{\text {inp }}$ input resistance; RMP, resting membrane potential.

corded 5-7 d after engraftment generated single, broad action potentials of relatively small amplitude (Fig. $2 A_{1}, A_{2}$, top panels; $B)(n=17$ of 24 recorded ESNs). The remaining 7 cells did not display action potentials during current injection. At later time points (12-15 and 19-21 d after transplantation; $n=9$ and 20, respectively), ESNs invariably exhibited action potentials (Fig. $2 A_{1}, A_{2}$, bottom panels), with the action potential half-width decreasing, the amplitude increasing, and the action potential threshold becoming more hyperpolarized $(B)$. Furthermore, ESNs at later stages increasingly displayed repetitive firing, which was never observed in the early group (Fig. $2 A_{1}, B_{3}$ ). The intrinsic firing properties and the action potential parameters at late stages of ESN differentiation (19-21 d) increasingly resembled those observed in host granule neurons analyzed within the same time range (Fig. $2 B_{1}-B_{4}$ ).

The maturation of the intrinsic discharge behavior observed in ESNs was paralleled by the development of voltage-dependent membrane currents. A minority of cells at all of the time points lacked voltage-dependent ionic conductances ( 4 of 24,1 of 9 , and 1 of 20 cells at $5-7,12-14$, and $19-21 \mathrm{~d}$ after transplantation, respectively). In all of the other cells, both inward and outward currents of variable amplitude coexisted. Outward currents recorded in voltage-clamp mode with the voltage step protocol shown in the inset of Figure $2 C_{1}$ revealed increasing amplitudes of sustained $\mathrm{K}^{+}$currents $\left(I_{\mathrm{K}, \text { sust }}\right)$ with time in culture $\left(C_{1}, D_{1}\right)$. 
The amplitude of the decaying component of the $\mathrm{K}^{+}$current $\left(I_{\mathrm{K}, \text { trans }}\right)$ also increased significantly with time in culture (Fig. $2 D_{2}$ ).

Fast inward currents could also be observed during depolarizing voltage steps. These inward currents were completely blocked by $500 \mathrm{~nm}$ TTX $(n=3)$ and, thus, corresponded to voltage-gated $\mathrm{Na}^{+}$currents (Fig. $2 C_{2}$, asterisk). Similar to $I_{\mathrm{K}, \text { sust }}$, the maximal amplitudes of voltage-gated $\mathrm{Na}^{+}$currents $\left(I_{\mathrm{Na}}\right)$ increased with time $\left(D_{3}\right)$. It has to be noted that the recordings of these currents, in particular $I_{\mathrm{Na}}$, may be distorted by inadequate clamp of extended neuronal processes. Nevertheless, such recordings permit an estimate of maximal current amplitudes.

\section{ESNs express ionotropic}

neurotransmitter receptors and receive excitatory and inhibitory synaptic input A prerequisite for the communication of ESNs with other neurons is the formation of excitatory and inhibitory synaptic contacts. We first tested whether incorporated ESNs express ionotropic AMPA and GABA receptors using antibodies against the GluR1 AMPA receptor subunit and the $\mathrm{GABA}_{\mathrm{A}}$ receptor $\beta$-chain, respectively (Fig. $3 A_{1}-A_{3}, n=6$ slices; $A_{1}-A_{3}, n=4$ slices). Both subunits were clearly detectable in the membrane of most $\mathrm{EGFP}^{+}$neurons (Figs. 3 and 4, compare $A_{1}$ and $A_{2}$ ).

We then examined whether the expression of these neurotransmitter receptor subunits reflects the presence of functional glutamatergic and GABAergic synapses on ESNs. We recorded spontaneous postsynaptic currents [miniature EPSCs (mEPSCs)] in the presence of bicuculline $(10 \mu \mathrm{M})$ and AP5 $(50 \mu \mathrm{M})$ to isolate synaptic currents mediated by AMPA receptors 12-14 d after transplantation of ES cell-derived neural precursors. Under these recording conditions, mEPSCs with a fast time course were observed (10-90\% rise time, $1.2 \pm 0.2 \mathrm{msec}$; decay time constant, $4.2 \pm$ $1.6 \mathrm{msec}$ ) (Fig. $3 B_{1}, B_{2}$ ), which were completely abolished after additional application of $50 \mu \mathrm{M}$ CNQX $\left(B_{3}\right)(n=10)$. The reversal potential of AMPA receptormediated EPSCs was examined after synaptic stimulation with a monopolar stimulation electrode (Fig. $3 C_{1}$ ) and proved to be close to $0 \mathrm{mV}\left(C_{2}\right)(n=4)$. In all these cases, synaptically mediated EPSCs were completely blocked by $50 \mu \mathrm{M}$ CNQX, confirming that they were exclusively mediated by AMPA receptors.

Synaptic miniature IPSCs mediated by $\mathrm{GABA}_{\mathrm{A}}$ receptors were isolated by combined application of AP5 and CNQX (both 50 $\mu \mathrm{M})$ and displayed a slower time course (10-90\% rise time, $1.6 \pm$ $0.3 \mathrm{msec}$; decay time constant, $17.6 \pm 1.9 \mathrm{msec}$ ) (Fig. $4 B_{1}, B_{2}$ ).
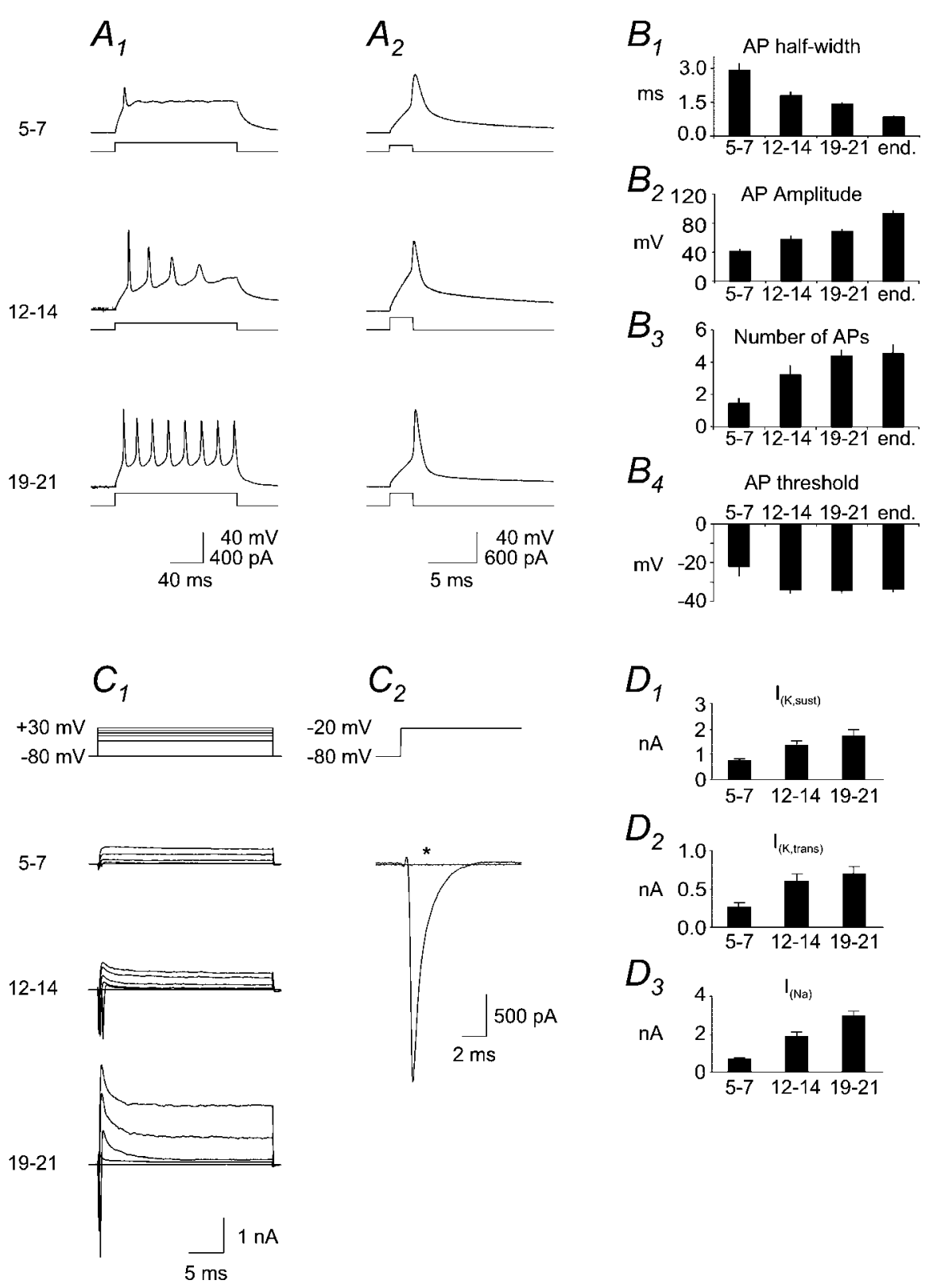

Figure 2. Intrinsic discharge properties and expression of voltage-gated membrane currents observed in engrafted ESNs. A, Currentclamp recordings during prolonged $\left(A_{1}\right)$ and brief $\left(A_{2}\right)$ current injections at different time points after transplantation (5-7, 12-14, and 19-12 d, as indicated at the left). Top traces represent voltage recordings, whereas bottom traces indicate current injections. $B$, Development of action potential (AP) parameters with time in culture. Action potential half-width $\left(B_{7}\right)$ was measured at the half-maximal amplitude. Action potential amplitude was measured from the beginning of the fast upstroke to the peak amplitude $\left(B_{2}\right)$. The number of action potentials was evaluated during a $150 \mathrm{msec}$ current injection that was twofold higher than a threshold current injection $\left(B_{3}\right)$. The action potential threshold was defined as the voltage at which the slope of the voltage trace changed abruptly. Note the progressive development of repetitive discharge properties and action potential morphology with time in culture $(A, B)$. For comparison, the properties of endogenous (end.) neurons within the slice culture granule cell layer are shown ( $B_{1}-B_{4}$, rightmost bars). $C$, Voltage-dependent membrane currents. Depolarizing voltage steps (see insets) elicited outward currents with a transiently decaying $\left(I_{\mathrm{K}, \text { trans }}\right)$ and a sustained $\left(I_{K, \text { sust }}\right)$ component $\left(C_{7}\right)$. In addition, we observed fast inward currents that were blocked by application of $\Pi X X\left(C_{2}\right.$, asterisk). D, Maximal amplitudes of transiently decaying $\left(I_{K, \text { trans }}\right)$ and sustained $\left(I_{K, \text { sust }}\right)$ outward-current components, as well asfast Na ${ }^{+}$inward currents $\left(I_{\mathrm{Na}}\right)$. The amplitude of $I_{K, \text { trans }}$ was determined by subtracting sustained outward-current amplitudes at the end of the command pulse from the peak outward-current amplitude.

These IPSCs were completely blocked by application of $10 \mu \mathrm{M}$ bicuculline (Fig. $\left.4 B_{3}\right)(n=7)$, confirming that these currents were mediated by $\mathrm{GABA}_{\mathrm{A}}$ receptors. The reversal potential of synaptically evoked $\mathrm{GABA}_{\mathrm{A}}$ receptor-mediated currents was approximately $-40 \mathrm{mV}$, close to the calculated $\mathrm{Cl}^{-1}$ reversal po- 

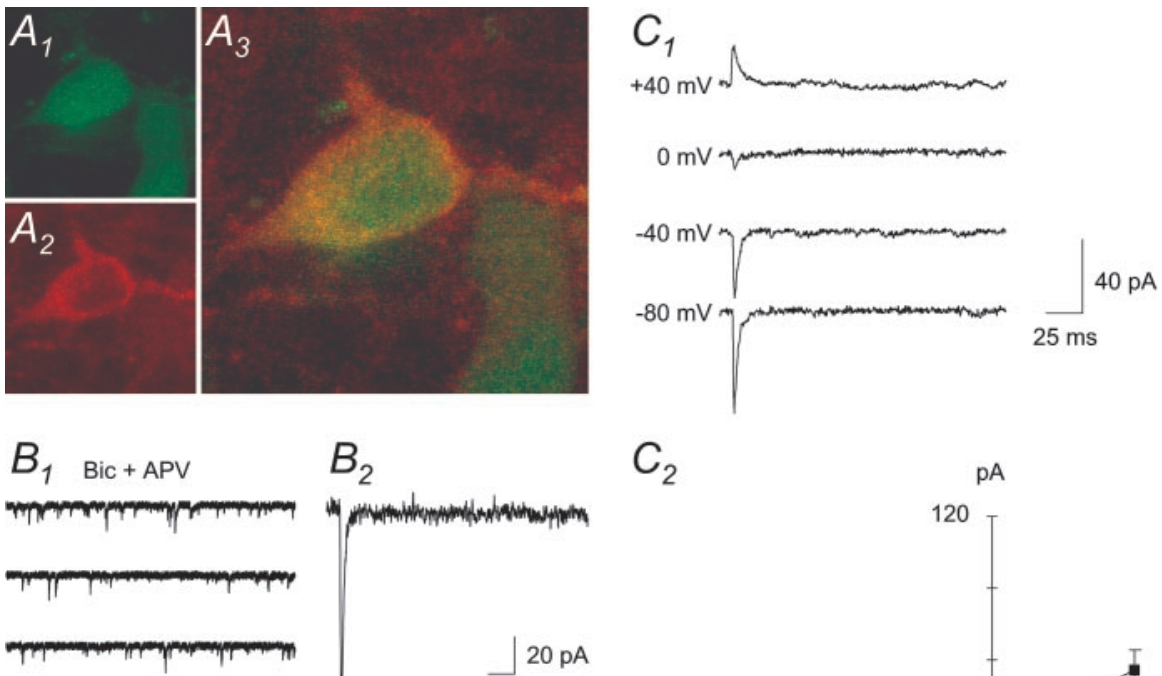

$B_{2}$

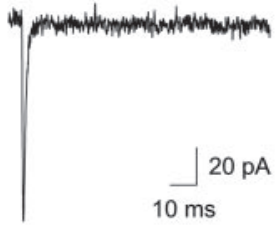

$B_{3}+\mathrm{CNQX}$
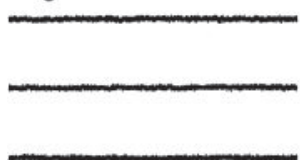

$\underset{\square}{\square} \mathrm{pA}$

$\mathrm{C}_{2}$

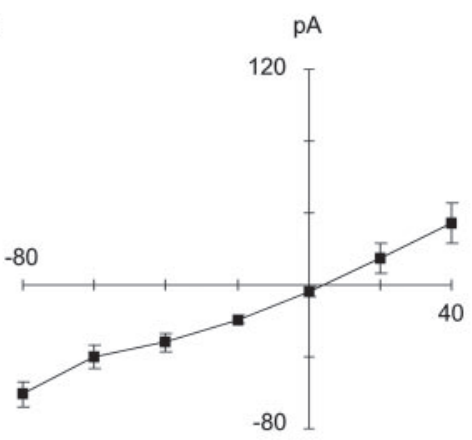

Figure 3. AMPA receptor-mediated synaptic transmission onto ESNs. $A_{1}-A_{3}$, ESNs express AMPA GluR1 subunits. Twelve days after deposition on the slice culture, an incorporated EGFP ${ }^{+}$donor cell $\left(A_{1}\right)$ displays immunoreactivity with a GluR1 antibody $\left(A_{2}\right)$; overlay $\left(A_{3}\right) \cdot B_{1}-B_{3}$, Spontaneous postsynaptic currents were recorded in the presence of bicuculline (Bic) (10 $\mu \mathrm{m}$ ) and AP5 (APV) $(50 \mu \mathrm{M})$ to isolate synaptic currents mediated by AMPA receptors $\left(B_{1}\right)$ (larger magnification in $\left.B_{2}\right)(12-14 \mathrm{~d}$ after engraftment). EPSCs were completely abolished after additional application of $50 \mu \mathrm{M} C \mathrm{CNQX}\left(B_{3}\right) \cdot C_{1}, C_{2}$, To estimate the reversal potential, the cell membrane was clamped at the potentials indicated $\left(C_{1}\right.$, left $)$, and AMPA receptor-mediated EPSCs were elicited by synaptic stimulation with a monopolar stimulation electrode. Current amplitudes were averaged and plotted at each holding potential. The reversal potential was close to $0 \mathrm{mV}\left(C_{2}\right)$.

tential of $-36 \mathrm{mV}$ for our recording conditions (Fig. $4 C_{1}, C_{2}$ ) $(n=3)$. Stimulation-evoked $\mathrm{GABA}_{\mathrm{A}}$-mediated IPSCs were completely blocked by $10 \mu \mathrm{M}$ bicuculline in all of the cases.

We also examined whether NMDA receptor-mediated EPSCs can be recorded from ESNs in the presence of CNQX $(50 \mu \mathrm{M})$ and bicuculline $(10 \mu \mathrm{M} ; n=52)$. In these recordings, glycine $(5 \mu \mathrm{M})$ was added to the recording solution to increase the amplitude of NMDA-mediated currents. In addition, $\mathrm{Mg}^{2+}$ was omitted from the extracellular solution in some of the recordings $(n=18)$. Only a single donor cell showed AP5-sensitive spontaneous EPSCs in the presence of CNQX and bicuculline. In another ESN, AP5-sensitive EPSCs could be elicited by synaptic stimulation with a monopolar stimulation electrode and showed a characteristic nonlinear $I-V$ relationship in the presence of $1 \mathrm{~mm}$ extracellular $\mathrm{Mg}^{2+}$ (data not shown). Thus, the contribution of NMDA receptors to the synaptic input converging on ESNs appears to be negligible, although immunocytochemistry suggested that they contain the NR1 subunit of the NMDA receptor ( $n=3$ slices) (data not shown). In contrast, endogenous granule neurons in the slice culture displayed prominent NMDA-mediated synaptic responses $(n=4$; average amplitude at $0 \mathrm{mV}, 61.5 \mathrm{pA}$; rise time, $13.1 \mathrm{msec} ; \tau, 79.6 \mathrm{msec}$ ) with a characteristic nonlinear $I-V$ relationship ( $1 \mathrm{~mm}$ extracellular $\mathrm{Mg}^{2+}$ ) (data not shown).

\section{Development of synaptic input onto ESNs with time in culture}

The distinct decay time course of AMPA and $\mathrm{GABA}_{\mathrm{A}}$ receptormediated synaptic PSCs (Figs. 3 and 4) as well as the scarcity of NMDA-mediated EPSCs in ESNs allowed a clear discrimination of spontaneous $\mathrm{GABA}_{\mathrm{A}^{-}}$and AMPAmediated events in recordings in which blockers of neurotransmitter receptors were omitted. This permitted us to analyze the presence of AMPA and/or $\mathrm{GABA}_{\mathrm{A}}$ receptor-mediated synaptic transmission in individual ESNs at different time points after engraftment. A dramatic increase in the frequency of both AMPA- and $\mathrm{GABA}_{\mathrm{A}}$-mediated spontaneous PSCs was observed after incorporation of ESNs into the host tissue. Whereas 5-7 d after transplantation, only 15 of 42 neurons displayed spontaneous synaptic activity, PSCs were observed in the vast majority of ESNs at later stages (days 12-14, 23 of 25 neurons; days 19-21, 44 of 49 neurons).

At the earliest time point, the frequency of PSCs was very low even in those ESNs in which synaptic activity was observed, and subsequently increased considerably with time after transplantation (Fig. $5 A_{1}-$ $\left.A_{3}, B_{1}, B_{2}\right)$. The average amplitude of PSCs also increased modestly (Fig. $5 C_{1}, C_{2}$ ). Notably, ESNs that did show spontaneous synaptic activity always exhibited both AMPA and GABAergic PSCs. These data indicate that engrafted ESNs receive progressively increasing GABAergic and glutamatergic input.

In a number of experiments, we analyzed both the intrinsic discharge behavior of ESNs and their synaptic input $(n=53)$. Interestingly, a subset of cells analyzed at early stages (5-7 d after transplantation) was found to generate single action potentials but did not exhibit spontaneous synaptic activity ( 5 of 24 cells analyzed). In contrast, neurons that displayed synaptic activity invariably fired action potentials.

\section{Incorporated ESNs receive input from host axonal projections}

The hippocampal slice preparation used as recipient tissue for ESNs contains both the hippocampus and the entorhinal cortex. Entorhinal cortex neurons give rise to the perforant path, the main afferent projection to the hippocampus. Preservation of the perforant path was visualized by depositing a small amount of rhodamine-conjugated dextran onto the entorhinal cortex. Dye uptake by cortical neurons and subsequent anterograde axonal transport of the conjugated dextran resulted in intense fluorescent staining of perforant path axons, allowing us to visualize contact sites between projecting axons and donor cell dendrites within the DG molecular layer (Fig. 6A). We next tested whether these putative contact points reflect functional synapses between host perforant path axons and ESNs within the dentate gyrus. To this end, we placed a monopolar stimulation electrode within the entorhinal cortex. To exclude direct stimulation of incorporated ESNs, we carefully examined the vicinity of the stimulation electrode for the presence of EGFP ${ }^{+}$axonal or dendritic profiles and excluded such slices from additional analysis. Stimulation of the host perforant path induced synaptic EPSCs $(n=5)$. We subsequently examined whether host fibers forming synapses on ESNs express presynaptic short-term plasticity (Fig. 6B). Paired-pulse stimulation at various interstimulus intervals $(20,40,100$, and 
$200 \mathrm{msec}$ ) resulted in paired-pulse facilitation of up to $200 \%$ (Fig. 6 B, bottom traces; $C$, open circles) $(n=4-5)$. Thus, incorporated ESNs receive functional glutamatergic synapses from host axons, which express pronounced short-term plasticity. We compared these data with perforant path synapses onto endogenous granule neurons $(n=4)$. In contrast to recordings from ESNs, these synapses exhibited paired-pulse depression in most experiments, with facilitation being observed in only one neuron (Fig. 6B, top traces; $C$, filled circles).

\section{Discussion}

Transplanted neural precursors derived from primary CNS tissue or cultured ES cells have been shown to integrate into the developing brain and differentiate into mature neurons and glia (Brüstle et al., 1995, 1997; Campbell et al., 1995; Fishell, 1995; Olsson et al., 1997; Zhang et al., 2001). The integration of these cells has been well characterized using morphological and immunohistochemical techniques. Moreover, the results of several studies indicate that primary and immortalized CNS stem cells as well as ES cellderived neural cells can contribute to behavioral improvement when grafted into rodent models of neurodegenerative or traumatic CNS lesions (Martinez-Serrano et al., 1995; Studer et al., 1998; McDonald et al., 1999; Björklund et al., 2002; Kim et al., 2002; Ourednik et al., 2002; Teng et al., 2002).

Recently, both native and immortalized fetal neural stem cells have been shown to receive functional synaptic contacts during transplantation into the embryonic and neonatal brain (Auerbach et al., 2000; Englund et al., 2002). In contrast, the question of how individual ESNs interact with host neuronal circuitry has been addressed by only a single study. In this set of experiments, dopaminergic neurons derived from Nurr1overexpressing ES cells were grafted into the striatum of 6-hydroxy-dopamine-lesioned rats, an animal model of Parkinson's disease (Kim et al., 2002). Functional analyses demonstrated that putative ESNs generate action potentials and provided evidence suggestive of synaptic host-graft interactions. However, the interpretation of these data was complicated by the lack of a vital donor cell label, precluding unequivocal identification of individual ESNs during the recordings. Positive identification of donor-derived neurons depended on retrospective tyrosine hydroxylase immunostaining of the recorded cells and was restricted to dopaminergic neurons.

The scarcity of electrophysiological data on the functional integration of ES cell-derived neurons after transplantation is sur-
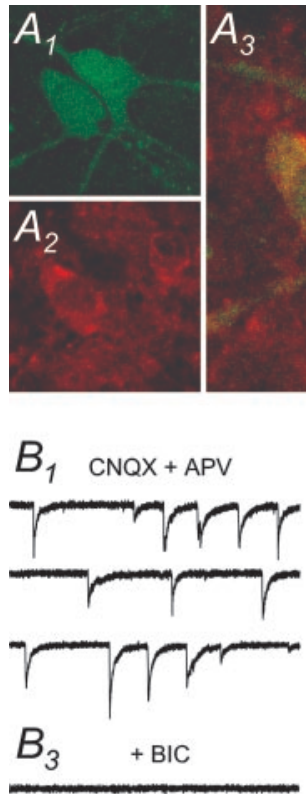
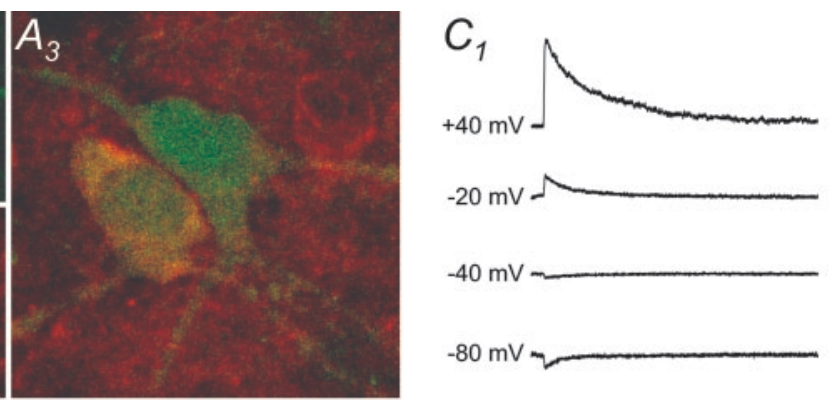

$B_{2}$

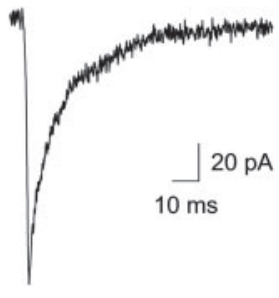

$C_{2}$
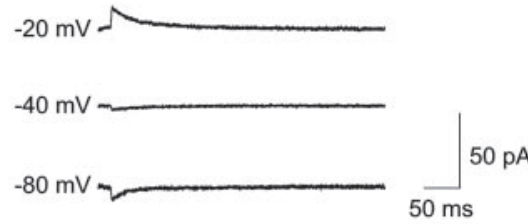
$50 \mathrm{pA}$

Figure 4. ESNs receive $\mathrm{GABA}_{\mathrm{A}}$ receptor-mediated synaptic input. $A_{1}-A_{3}$, Immunohistochemical detection of the $\mathrm{GABA}_{\mathrm{A}}$ receptor $\beta$-chain (red) in EGFP-labeled donor neurons ( $12 \mathrm{~d}$ after engraftment) $\left(A_{3}\right.$, overlay). $B_{1}-B_{3}$, Spontaneous GABA $A_{A}$ receptor-mediated synaptic currents were isolated by recording PSCs in the presence of $50 \mu \mathrm{M}$ CNQX and AP5 (APV) $\left(B_{1}\right)$ (larger magnification in $\left.B_{2}\right)(12-14$ $\mathrm{d}$ after engraftment). IPSCS were completely blocked after additional application of $10 \mu \mathrm{m}$ bicuculline $(\mathrm{BIC})\left(B_{3}\right) . C_{1}, C_{2}$, Determination of the reversal potential. Analogous to Figure 3 , the cell membrane was clamped at the potentials indicated $\left(C_{1}\right.$, left), and $G A B A_{A}$ receptormediated IPSCS were elicited by synaptic stimulation with a monopolar stimulation electrode. Current amplitudes were averaged and plotted at each holding potential. The reversal potential was approximately $-40 \mathrm{mV}\left(C_{2}\right)$.

$A_{1}$

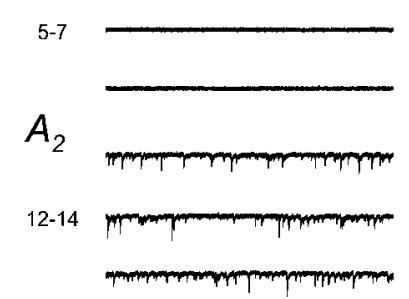

$A_{3}$

$19-21$

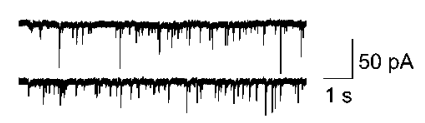

Figure 5. Development of synaptic input onto ESNs during engraftment into slice cultures. $A_{1}-A_{3}$, Representative examples of spontaneous synaptic activity at different time points after engraftment (indicated at the left) (recordings were taken without blockers of synaptic transmission). $B_{1}, B_{2}, C_{1}, C_{2}$, Putative AMPA- and $\mathrm{SABA}_{\mathrm{A}}$-mediated PSCs were separated on the basis of their different decay time constants (Fig. 4 and this figure). With time after engraftment, the average frequency of both types of synaptic events increased dramatically $\left(B_{1}, B_{2}\right)$. The average amplitude of AMPA-and $G A B A_{A}$-mediated PSC $S$ was similar in all of the age groups $\left(C_{1}, C_{2}\right)$. Error bars represent SD as described in Materials and Methods. prising in view of the fact that ES cells provide an extremely attractive alternative to fetal donor tissue. Major advantages of ES cells as donor source include their pluripotency, the potential for virtually unlimited proliferation (Evans and Kaufman, 1981; Martin, 1981), their amenability to genetic modification (Zimmer, 1992), and the possibility to differentiate them into purified neural cell populations ( $\mathrm{Li}$ et al., 1998; Okabe et al., 1996; Brüstle 


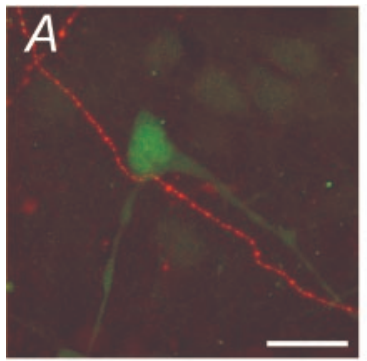

$B$
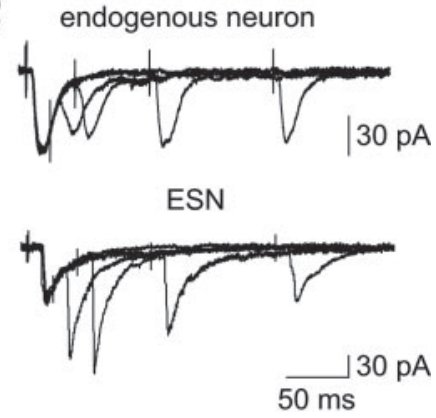

C

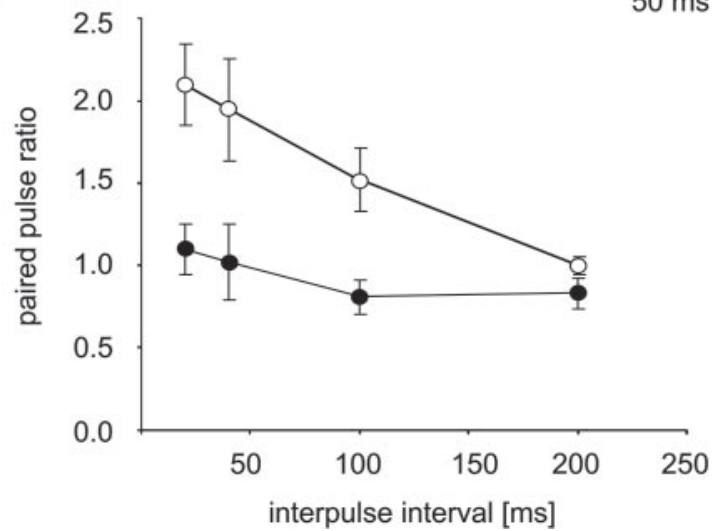

Figure 6. Incorporated ESNs receive input via the host perforant path. $A$, Afferent perforant path axons were traced by anterograde labeling with rhodamine-conjugated dextran (microruby). Labeled host axons were found to contact EGFP ${ }^{+}$ESNs incorporated into the DG granule cell layer. Scale bar, $10 \mu \mathrm{m}$. B, Synaptic PSCs in engrafted ESNs and adjacent host neurons within the granule cell layer, elicited by stimulation within the entorhinal cortex. Before recording, all of the samples were carefully examined for the presence of EGFP-positive axonal or dendritic profiles in the vicinity of the stimulation site; positive slices were excluded from additional analysis. Double-pulse experiments showed that perforant path axons terminating on ESNs exhibit marked paired-pulse facilitation (interpulse intervals, 20, 40, 100, and $200 \mathrm{msec}$ ) (bottom traces). In contrast, perforant path synapses onto endogenous neurons in the granule cell layer mostly displayed paired-pulse inhibition (top traces). C, Paired-pulse ratio calculated as the amplitude of the second divided by the amplitude of the first EPSC for incorporated ESNs (open circles) and endogenous neurons (filled circles).

et al., 1999; Rolletschek et al., 2001; Kawasaki et al., 2002; Mujtaba and Rao, 2002; Wernig et al., 2002). The availability of human ES cells has further promoted the interest in exploiting this unique cell type for cell transplantation and neural repair (Thomson et al., 1998).

In the present study, we examined the functional integration of ESNs into hippocampal slice cultures in detail. We used ES cells carrying the gene for EGFP targeted to the tau locus, permitting unequivocal identification of donor-derived neurons (Tucker et al., 2001; Heins et al., 2002; Wernig et al., 2002). This technique permits distinguishing ESNs from donor-derived glial cells, which are also found after transplantation of immature, multipotent neural precursor cells into hippocampal slice cultures (Scheffler et al., 2001). Our data demonstrate that ESNs incorporated into the host tissue exhibit a maturation of their intrinsic membrane properties and receive synaptic input from host neurons.

\section{Maturation of intrinsic donor cell properties}

Patch-clamp analyses at different time points after donor cell deposition showed that the incorporated ESNs undergo a gradual maturation. At early stages (5-7 d after deposition), only a small fraction of the donor-derived neurons was found to generate action potentials. In contrast, at later stages, ESNs exhibited dis- charge and passive membrane properties more similar to those of host neurons. Concomitantly, ESNs increasingly expressed different voltage-dependent inward and outward currents.

The intrinsic properties of ESNs have been examined previously in dispersed cell culture (Bain et al., 1995, Fraichard et al., 1995, Strübing et al., 1995). Unlike our protocol, which allows the derivation of comparatively pure populations of neural precursors and neurons (see Materials and Methods), retinoic acid treatment was used to induce ES cell differentiation in these experiments. Nevertheless, as in our study, virtually all of the neuron-like cells exhibited voltage-dependent $\mathrm{Na}^{+}, \mathrm{Ca}^{2+}$, and $\mathrm{K}^{+}$channels after $1-2$ weeks in culture, and repetitive action potential firing could be elicited by depolarizing current injections. Both passive membrane properties and the intrinsic firing behavior of ESNs increasingly approximated properties characteristic of mature neurons.

\section{Synaptic innervation of ESNs}

ESNs incorporated into the dentate gyrus displayed AMPA receptor-mediated EPSCs and GABAergic IPSCs similar to those observed in adult dentate granule cells (Keller et al., 1991; Draguhn and Heinemann, 1996). Functional AMPA and $\mathrm{GABA}_{\mathrm{A}}$ receptors have been detected previously in retinoic acid-induced ESNs in dispersed culture (Bain et al., 1995; Strübing et al., 1995; Finley et al., 1996). Some of the cultured ESNs were found to form inhibitory and excitatory synaptic contacts with each other (Strübing et al., 1995; Finley et al., 1996). These synapses mostly developed after 5-11 d in vitro, comparable with the increase in spontaneous glutamatergic and GABAergic PSCs observed in engrafted ESNs in this study. Similar to our findings, Strübing et al. (1995) observed early ESNs, which had the capability to generate action potentials but received no synaptic input, whereas the converse was never true. Together, these data suggest that the formation of active membrane properties in ESNs may precede the formation of afferent synaptic contacts.

In contrast to abundant synaptic input mediated by AMPA and $\mathrm{GABA}_{\mathrm{A}}$ receptors, most ESNs did not exhibit NMDA receptor-mediated EPSCs, despite the presence of clear immunostaining for the NR1 subunit of the NMDA receptor. The absence of NMDA receptor-mediated excitatory neurotransmission is in contrast to the granule neurons we analyzed in the host slice cultures, and to reported data on granule neurons in acute hippocampal slices (Keller et al., 1991), but similar to synapses between ES cell-derived neurons in dispersed cell culture (Finley et al., 1996).

This paucity of NMDA receptor-mediated excitatory neurotransmission in cultured and engrafted ESNs could be attributable to several factors. NMDA receptors are multimeric proteins. Six different subunits have been cloned in the rat (NR1, NR2ANR2D, and NR3A) (Moriyoshi et al., 1991; Das et al., 1998) and in the mouse (homologous subunits $\zeta 1, \epsilon 1-\epsilon 4$, and $\chi 1$ ) (Kutsuwada et al., 1992; Ciabarra et al., 1995). Coassembly of the NR1/ $\zeta$ subunit with any member of the NR2/ $\epsilon$ family yields functional NMDA receptors with distinct functional properties (Monyer et al., 1992, 1994). Because ESNs within the slice cultures express NR1, the lack of NMDA receptor-mediated synaptic currents could be attributable to the absence of functional NR2 subunits. Although this possibility was not excluded in the present study, it seems unlikely that the ESNs lack all four NR2/ $\epsilon$ subunits. Alternatively, targeting of NMDA receptors to the postsynaptic density of ESNs might be impaired. This process is regulated by cellautonomous signal transduction cascades (Henderson et al., 2001) and may also be influenced by cues derived from the pre- 
synapse (Mi et al., 2002). This cross- talk between presynapse and postsynapse might be impaired in the xenogeneic paradigm used in this study. Finally, the in vitro propagation of ES cell-derived neural precursors might lead to the selection of NMDA receptordeficient, potentially less vulnerable phenotypes. Regardless of the underlying mechanism, a lack of NMDA receptor-mediated synaptic input might affect maturation of engrafted ESNs. For instance, a number of studies have demonstrated that blocking NMDA receptors promotes cell proliferation in the dentate gyrus (Gould et al., 1994; Cameron et al., 1995).

\section{Incorporated ESNs receive input via host axonal projections}

Our experimental paradigm allowed us to address the important question of whether ESNs receive excitatory synaptic input from host neurons. To this end, we made use of the fact that most ESNs integrated within the dentate gyrus, which receives a well ordered afferent projection from the entorhinal cortex that is conserved in our slice cultures (Kluge et al., 1998) (Fig. 6), and from which $\mathrm{EGFP}^{+}$axonal and dendritic profiles were absent. EPSCs elicited by stimulation of the perforant path within the entorhinal cortex could thus unequivocally be attributed to synapses between host neurons and ESNs.

A striking short-term plasticity could be observed in perforant path synapses onto ESNs. In double-pulse experiments with short interstimulus intervals $(20-100 \mathrm{msec})$, the second EPSC displayed marked paired-pulse facilitation. In contrast, stimulation of the perforant path while recording from endogenous neurons within the dentate granule cell layer caused paired-pulse inhibition in most neurons. It has been suggested that immature perforant path synapses onto newly formed granule cells display a high degree of paired-pulse facilitation, whereas mature synapses at later developmental stages show less facilitation or depression (Wang et al., 2000). Thus, host perforant path axons form synapses onto ESNs and display a form of presynaptic short-term plasticity also observed in immature perforant path synapses.

In a recent study, evidence suggestive of synaptic contacts between grafted ESNs and host neurons has been presented (Kim et al., 2002). Paired recordings of ESNs and host neurons failed to demonstrate host-graft connections, but stimulation within the graft elicited EPSPs in host neurons outside the graft. Conversely, stimulation in the vicinity of the graft yielded IPSPs in putative donor neurons. The interpretation of these observations is complicated by the lack of a vital donor cell label that allows clear identification of donor cell processes in vitro. Thus, the possibility remains that PSPs recorded in the graft area were caused by stimulation of donor cell processes. In the experiments reported here, this critical issue was bypassed by the use of ES cells engineered to express EGFP in neuronal progeny, providing unequivocal evidence of functional host-graft synapses. Together, both studies strongly support the notion that ESNs have the capacity to functionally integrate into CNS tissue.

Nevertheless, several important issues associated with the integration of ESNs into preexisting neuronal networks remain to be investigated. For example, it is not clear how migration of ESNs is regulated, and how ESNs might be induced to migrate to specific locations within the host tissue. With respect to functional integration, it is currently unclear whether and to what extent ESNs form synapses onto host neurons, how divergent this synaptic connectivity may be, and what types of synapses are formed. Clarifying these issues will require paired recordings from ESNs and their host target neurons, an exceptionally challenging task. The process of functional integration might be influenced not only by host factors but also by glial cells originating from the grafted precursor cell population (Scheffler et al., 2001). The accessibility of the slice culture paradigm and the possibility to combine donor cells and recipient tissue from different genetic backgrounds will make this system particularly useful for addressing these issues.

It is important to realize that this study focuses on ESNs integrated within or close to the dentate granule cell layer. The development of this area extends well into the neonatal phase, and it retains an unmatched synaptic and cellular plasticity throughout adulthood. The granule cell layer represents one of the few niches for lifelong neurogenesis and may constitute an environment that is particularly supportive for functional integration of exogenous neurons. Thus, although our results clearly demonstrate that ESNs integrate within the dentate gyrus, additional work is required to address functional donor cell integration in other brain regions. The results of these studies will be essential for the development of ES cell-based neuronal repair strategies.

\section{References}

Alvarez-Buylla A, Garcia-Verdugo JM (2002) Neurogenesis in adult subventricular zone. J Neurosci 22:629-634.

Auerbach JM, Eiden MV, McKay RD (2000) Transplanted CNS stem cells form functional synapses in vivo. Eur J Neurosci 12:1696-1704.

Bain G, Kitchens D, Yao M, Huettner JE, Gottlieb DI (1995) Embryonic stem cells express neuronal properties in vitro. Dev Biol 168:342-357.

Björklund A, Lindvall O (2000) Cell replacement therapies for central nervous system disorders. Nat Neurosci 3:537-544.

Björklund LM, Sanchez-Pernaute R, Chung S, Andersson T, Chen IY, McNaught KS, Brownell AL, Jenkins BG, Wahlestedt C, Kim KS, Isacson O (2002) Embryonic stem cells develop into functional dopaminergic neurons after transplantation in a Parkinson rat model. Proc Natl Acad Sci USA 99:2344-2349.

Brüstle O, Maskos U, McKay RD (1995) Host-guided migration allows targeted introduction of neurons into the embryonic brain. Neuron 15:1275-1285.

Brüstle O, Spiro AC, Karram K, Choudhary K, Okabe S, McKay RD (1997) In vitro-generated neural precursors participate in mammalian brain development. Proc Natl Acad Sci USA 94:14809-14814.

Brüstle O, Jones KN, Learish RD, Karram K, Choudhary K, Wiestler OD, Duncan ID, McKay RD (1999) Embryonic stem cell-derived glial precursors: a source of myelinating transplants. Science 285:754-756.

Cameron HA, McEwen BS, Gould E (1995) Regulation of adult neurogenesis by excitatory input and NMDA receptor activation in the dentate gyrus. J Neurosci 15:4687-4692.

Campbell K, Olsson M, Björklund A (1995) Regional incorporation and site-specific differentiation of striatal precursors transplanted to the embryonic forebrain ventricle. Neuron 15:1259-1273.

Ciabarra AM, Sullivan JM, Gahn LG, Pecht G, Heinemann S, Sevarino KA (1995) Cloning and characterization of chi-1: a developmentally regulated member of a novel class of the ionotropic glutamate receptor family. J Neurosci 15:6498-6508.

Das S, Sasaki YF, Rothe T, Premkumar LS, Takasu M, Crandall JE, Dikkes P, Conner DA, Rayudu PV, Cheung W, Chen HS, Lipton SA, Nakanishi N (1998) Increased NMDA current and spine density in mice lacking the NMDA receptor subunit NR3A. Nature 393:377-381.

Draguhn A, Heinemann U (1996) Different mechanisms regulate IPSC kinetics in early postnatal and juvenile hippocampal granule cells. J Neurophysiol 76:3983-3993.

Englund U, Björklund A, Wictorin K, Lindvall O, Kokaia M (2002) Grafted neural stem cells develop into functional pyramidal neurons and integrate into host cortical circuitry. Proc Natl Acad Sci USA 99:17089-17094.

Evans MJ, Kaufman MH (1981) Establishment in culture of pluripotential cells from mouse embryos. Nature 292:154-156.

Finley MF, Kulkarni N, Huettner JE (1996) Synapse formation and establishment of neuronal polarity by P19 embryonic carcinoma cells and embryonic stem cells. J Neurosci 16:1056-1065.

Fishell G (1995) Striatal precursors adopt cortical identities in response to local cues. Development 121:803-812.

Fraichard A, Chassande O, Bilbaut G, Dehay C, Savatier P, Samarut J (1995) 
In vitro differentiation of embryonic stem cells into glial cells and functional neurons. J Cell Sci 108:3181-3188.

Gage FH, Ray J, Fisher LJ (1995) Isolation, characterization, and use of stem cells from the CNS. Annu Rev Neurosci 18:159-192.

Gage FH, Kempermann G, Palmer TD, Peterson DA, Ray J (1998) Multipotent progenitor cells in the adult dentate gyrus. J Neurobiol 36:249-266.

Gähwiler BH (1981) Organotypic monolayer cultures of nervous tissue. J Neurosci Methods 4:329-342.

Gähwiler BH, Capogna M, Debanne D, McKinney RA, Thompson SM (1997) Organotypic slice cultures: a technique has come of age. Trends Neurosci 20:471-477.

Gould E, Cameron HA, McEwen BS (1994) Blockade of NMDA receptors increases cell death and birth in the developing rat dentate gyrus. J Comp Neurol 340:551-565.

Heins N, Malatesta P, Cecconi F, Nakafuku M, Tucker KL, Hack MA, Chapouton P, Barde YA, Götz M (2002) Glial cells generate neurons: the role of the transcription factor Pax6. Nat Neurosci 5:308-315.

Henderson JT, Georgiou J, Jia Z, Robertson J, Elowe S, Roder JC, Pawson T (2001) The receptor tyrosine kinase EphB2 regulates NMDA-dependent synaptic function. Neuron 32:1041-1056.

Kawasaki H, Suemori H, Mizuseki K, Watanabe K, Urano F, Ichinose H, Haruta M, Takahashi M, Yoshikawa K, Nishikawa S, Nakatsuji N, Sasai Y (2002) Generation of dopaminergic neurons and pigmented epithelia from primate ES cells by stromal cell-derived inducing activity. Proc Natl Acad Sci USA 99:1580-1585.

Keller BU, Konnerth A, Yaari Y (1991) Patch clamp analysis of excitatory synaptic currents in granule cells of rat hippocampus. J Physiol (Lond) 435:275-293.

Kim JH, Auerbach JM, Rodriguez-Gomez JA, Velasco I, Gavin D, Lumelsky N, Lee SH, Nguyen J, Sanchez-Pernaute R, Bankiewicz K, McKay R (2002) Dopamine neurons derived from embryonic stem cells function in an animal model of Parkinson's disease. Nature 418:50-56.

Kluge A, Hailer NP, Horvath TL, Bechmann I, Nitsch R (1998) Tracing of the entorhinal-hippocampal pathway in vitro. Hippocampus 8:57-68.

Kutsuwada T, Kashiwabuchi N, Mori H, Sakimura K, Kushiya E, Araki K, Meguro H, Masaki H, Kumanishi T, Arakawa M, Mishina M (1992) Molecular diversity of the NMDA receptor channel. Nature 358:36-41.

Li E, Bestor TH, Jaenisch R (1992) Targeted mutation of the DNA methyltransferase gene results in embryonic lethality. Cell 69:915-926.

Lindvall O (2001) Parkinson disease. Stem cell transplantation. Lancet 358 [Suppl]:S48.

Martin GR (1981) Isolation of a pluripotent cell line from early mouse embryos cultured in medium conditioned by teratocarcinoma stem cells. Proc Natl Acad Sci USA 78:7634-7638.

Martinez-Serrano A, Fischer W, Björklund A (1995) Reversal of agedependent cognitive impairments and cholinergic neuron atrophy by NGF-secreting neural progenitors grafted to the basal forebrain. Neuron 15:473-484.

McDonald JW, Liu XZ, Qu Y, Liu S, Mickey SK, Turetsky D, Gottlieb DI, Choi DW (1999) Transplanted embryonic stem cells survive, differentiate and promote recovery in injured rat spinal cord. Nat Med 5:1410-1412.

Mi R, Tang X, Sutter R, Xu D, Worley P, O’Brien RJ (2002) Differing mechanisms for glutamate receptor aggregation on dendritic spines and shafts in cultured hippocampal neurons. J Neurosci 22:7606-7616.

Monyer H, Sprengel R, Schoepfer R, Herb A, Higuchi M, Lomeli H, Burnashev N, Sakmann B, Seeburg PH (1992) Heteromeric NMDA receptors: molecular and functional distinction of subtypes. Science 256:1217-1221.

Monyer H, Burnashev N, Laurie DJ, Sakmann B, Seeburg PH (1994) Developmental and regional expression in the rat brain and functional properties of four NMDA receptors. Neuron 12:529-540.

Moriyoshi K, Masu M, Ishii T, Shigemoto R, Mizuno N, Nakanishi S (1991) Molecular cloning and characterization of the rat NMDA receptor. Nature 354:31-37.
Mujtaba T, Rao MS (2002) Isolation of lineage-restricted neural precursors from cultured ES cells. Methods Mol Biol 185:189-204.

Okabe S, Forsberg-Nilsson K, Spiro AC, Segal M, McKay RD (1996) Development of neuronal precursor cells and functional postmitotic neurons from embryonic stem cells in vitro. Mech Dev 59:89-102.

Olsson M, Campbell K, Turnbull DH (1997) Specification of mouse telencephalic and mid-hindbrain progenitors following heterotopic ultrasound-guided embryonic transplantation. Neuron 19:761-772.

Ourednik J, Ourednik V, Lynch WP, Schachner M, Snyder EY (2002) Neural stem cells display an inherent mechanism for rescuing dysfunctional neurons. Nat Biotechnol 20:1103-1110.

Reubinoff BE, Itsykson P, Turetsky T, Pera MF, Reinhartz E, Itzik A, Ben-Hur T (2001) Neural progenitors from human embryonic stem cells. Nat Biotechnol 19:1134-1140.

Rolletschek A, Chang H, Guan K, Czyz J, Meyer M, Wobus AM (2001) Differentiation of embryonic stem cell-derived dopaminergic neurons is enhanced by survival-promoting factors. Mech Dev 105:93-104.

Scheffler B, Horn M, Blümcke I, Laywell ED, Coomes D, Kukekov VG, Steindler DA (1999) Marrow-mindedness: a perspective on neuropoiesis. Trends Neurosci 22:348-357.

Scheffler B, Schmandt T, Schröder W, Steinfarz B, Wellmer J, Beck H, Steinhäuser C, Blümcke I, Wiestler OD, Brüstle O (2001) Network integration of embryonic stem cell-derived glial precursors. Soc Neurosci Abstr 31:370.1.

Stoppini L, Buchs PA, Müller D (1991) A simple method for organotypic cultures of nervous tissue. J Neurosci Methods 37:173-182.

Strübing C, Ahnert-Hilger G, Shan J, Wiedenmann B, Hescheler J, Wobus AM (1995) Differentiation of pluripotent embryonic stem cells into the neuronal lineage in vitro gives rise to mature inhibitory and excitatory neurons. Mech Dev 53:275-287.

Strübing C, Rohwedel J, Ahnert-Hilger G, Wiedenmann B, Hescheler J, Wobus AM (1997) Development of G protein-mediated $\mathrm{Ca}^{2+}$ channel regulation in mouse embryonic stem cell-derived neurons. Eur J Neurosci 9:824-832.

Studer L, Tabar V, McKay RD (1998) Transplantation of expanded mesencephalic precursors leads to recovery in parkinsonian rats. Nat Neurosci 1:290-295.

Teng YD, Lavik EB, Qu X, Park KI, Ourednik J, Zurakowski D, Langer R, Snyder EY (2002) Functional recovery following traumatic spinal cord injury mediated by a unique polymer scaffold seeded with neural stem cells. Proc Natl Acad Sci USA 99:3024-3029.

Thomson JA, Itskovitz-Eldor J, Shapiro SS, Waknitz MA, Swiergiel JJ, Marshall VS, Jones JM (1998) Embryonic stem cell lines derived from human blastocysts. Science 282:1145-1147.

Tucker KL, Meyer M, Barde YA (2001) Neurotrophins are required for nerve growth during development. Nat Neurosci 4:29-37.

van Praag H, Schinder AF, Christie BR, Toni N, Palmer TD, Gage FH (2002) Functional neurogenesis in the adult hippocampus. Nature 415:1030-1034.

Wang S, Scott BW, Wojtowicz JM (2000) Heterogenous properties of dentate granule neurons in the adult rat. J Neurobiol 42:248-257.

Wernig M, Tucker KL, Gornik V, Schneiders A, Buschwald R, Wiestler OD, Barde YA, Brüstle O (2002) Tau EGFP embryonic stem cells: an efficient tool for neuronal lineage selection and transplantation. J Neurosci Res 69:918-924.

Zhang SC, Wernig M, Duncan ID, Brüstle O, Thomson JA (2001) In vitro differentiation of transplantable neural precursors from human embryonic stem cells. Nat Biotechnol 19:1129-1133.

Zimmer A (1992) Manipulating the genome by homologous recombination in embryonic stem cells. Annu Rev Neurosci 15:115-137.

Zimmer J, Gähwiler BH (1984) Cellular and connective organization of slice cultures of the rat hippocampus and fascia dentata. J Comp Neurol 228: $432-446$. 